\title{
The Role of Taboos in African Governance Systems
}

\begin{abstract}
SUMmary
In Africa traditions permeate every aspect of life and are used to explain every phenomenon in day-to-day activities. However, this inimitable feature has been watered down and further pushed to the background by the influx of foreign religions such as Christianity and Islam, as well as modernity. Nevertheless, indigenous cultures survive as an undercurrent and recently the Indigenous Knowledge System (IKS) has been gaining prominence in the academia. In this paper taboos are classified and their role played in the governance system is analysed with the aim to raise awareness of the peculiar features of African traditional religions, with particular focus on the Akan of Ghana and their unique role in the local governance system.
\end{abstract}

Keywords: taboos, governance, Akan worldview

\section{INTRODUCTION}

The large number of taboos are a unique feature in African Traditional Religion (ATR), however, over time this distinctive feature has lost its significance and has been watered down due modern science and technology and the influences of other religious beliefs, especially Christianity and Islam. In the words of Brempong (2006), "the African has been robbed and deprived of his attitude and all that is most sacred to him, his laws, his religion, wisdom and institutions are destroyed - the Christian churches and the mosques, their priests and priestesses, imams are most hateful to the traditions, customs and beliefs". Taboos have played an important role in traditional African societies and still have their influence felt in the modern societies. They help regulate life and property. One particular area where this is very much evident is among the Akan of Ghana, as taboos play a distinguished role in their governance.

During the inauguration of an Akan chief, as part of his authority to govern, he goes through the process of taking an oath and this oath includes accepting to do or not do certain things (taboos). In order to demonstrate and reinforce the bond between the chief and the community, the latter also pledges to stand by him and adhere to all norms of their community to bring his reign to success. Taboos provide the basis for chiefs and other persons in charge

Emmanuel Abeku Essel, PhD Student, National University Of Public

Service (emmanuel.abeku.essel@hallg.uni-nke.hu). 
of governance, to adhere to and they expect the people under their control to also respect these taboos in the same manner. Thus, taboos do not only constitute a part of African cultural heritage but also provide a good explanation for that heritage. It is an essential concept in African cultures and understanding them will enable one to better infer the psychological, religious and social behaviour.

Brempong asserts that "taboos are leadership icons for all those in charge of governance, thus at the beginning of office they ought to swear an oath which is a seal of approval and assurance to the state that as a leader all taboos in the community would be observed" (Brempong, 2006:3). He further goes on to say that taboos become the traditional commandments through which those in charge of governance are protected from social and spiritual ambivalences. Thus, upon the instalment of a leader one can agree with Brempong that his or her person becomes sacred due to the various taboos he or she observes.

According to Busia, "the chief may not be struck by any one, lest the ancestors bring misfortune upon the tribe. The chief may never walk bare footed lest he stumble. If he does stumble, the expected calamity has to be averted with sacrifice. His buttocks may not touch the ground. That, again, would bring misfortune" (Busia, 1968:23).

All these taboos are a reminder to those in charge of governance that they occupy a sacred position and they have an obligation to adhere to the norms, regulations, rules, laws they have sworn to uphold because these are necessary for governance of their communities. Recently, countries all over the world and especially in Africa, are trying to improve governance. Western governments, donor institutions, especially the World Bank are asking African governments to deepen governance in their respective countries. Certain indicators of good governance such as adherence to the rule of law, transparency, responsiveness, consensus building, equity and inclusiveness, effectiveness and efficiency, accountability, transparency and participation are being demanded from governments (Olowu-Sako, 2002).

People learn about taboos as children from their parents and grandparents. The learning process takes place during communal ceremonies and initiation rites. It also happens during day-to-day activities, when one is about to do something that is prohibited. Considering that IKS is relevant in contemporary developmental conversations and with special reference to indigenous governance, there is a need to investigate the current state of IKS as it relates to governance and taboos.

\section{TABoo Concepts}

The concept of a "taboo" is difficult to define. The word is borrowed from a Polynesian language. Taboo is defined as an element of all situations in which attitudes to values are expressed in terms of dangerous behaviour. A taboo has something to do with "sacredness", something that may be "forbidden", it may apply to a "person" or to a "thing" and may describe things that are "elements' or "devoted". Taboos have always existed even though the term was not defined before 1777 by Captain James Cook. He reports the word taboo as signifying something forbidden. Even though the definition of taboo has remained more or less the same over the years, in today's Western world, taboos are nevertheless not so strong social prohibitions as they once were. The concept of taboos indeed is difficult to define for it is a vast and constantly changing area.

Steiner concludes that a "taboo is concerned (1) with all the social mechanisms of obedience which have ritual significance; (2) with specific and restrictive behaviour in dangerous situations. One might say that taboo deals with the sociology of danger itself, for it is also concerned (3) with the 
protection of individuals who are in danger and (4) with the protection of the society from those endangered - and therefore dangerous - persons" (Steiner, 1956:21). However, Osei (2006) states that a taboo means "an akyiwade; that which is forbidden or prohibited".

Some taboos are considered to be global, but each culture also has its own peculiar set of taboos. Allan and Burridge mention that new taboos on sexuality, religion, gender, disability, race and ethnicity have appeared in English-speaking societies (Allan-Burridge, 2006:105). This phenomenon is also visible in Germany where today it is forbidden to reveal the ethnicity of criminals in newspapers. That is to say, German courts allow the names and ethnicities of criminals to be suppressed in news reports once they have paid their debt to society (Schwartz, 2009). Taboos do not remain the same over the years. New taboos appear constantly, whereas old ones change in content or form.

Crystal suggests that a clear line must be drawn between the language of taboo, the language of abuse and the language of swearing (Crystal, 1995:173). However, for non-native speakers all taboo words and phrases usually have a similar impact. In fact, despite its trend to embrace universal canons, our societies continue to be dominated by purely archaic taboos. Whether this trend is denied or accepted, it is widely recognized as indispensable for understanding contemporary life in Ghana and Africa as a whole.

According to Omobola (2013), in a historical context, "taboo" was a sacred term for a set of cultic or religious prohibitions instituted by traditional religious authorities as instruments for moral motivation, guidance and objectivity in order to protect the sanctity of shrines and the well-being of their worshipping communities. The term is also applicable to any sort of social prohibition imposed by the leadership of a community regarding certain times, places, ac- tions, events and people especially, but not exclusively, for religious reasons and the well-being of the society. Taboos may therefore be used in two senses. The narrower sense is cultic or purely religious, while the broader sense is socio-economic and political. A cultic or religious taboo comprises a subset of taboos, but does not represent taboos as a whole. For the same reason, religion is a useful, but not necessary condition for the existence of a taboo (Osei, 2006). Part of the problem in any discussion of taboos is the variety of definitions and uses of the word. However, it typically refers to prohibitions on particular people, objects or deeds. Nonetheless, the term "taboo" may also be used in the "predicative and adjectival sense" to refer to "persons, places, things or conditions invested with a mysterious attribute and the prohibitions arising from the same attribute" (Levine, 1986:995). Both the narrow and the broad interpretation of the term are evident in Akan (Fantes) and Ewe discourses on taboos. The closest equivalent to the term "taboo" in the Akan language is "akyiwade" or "musuo", or something that is forbidden or prohibited. The latter term is, however, reserved for prohibitions against very serious or extraordinary moral evils, such as murder, suicide, rape, incest and religious sacrilege. Therefore, while all akyiwade are taboos, not all taboos are musuo (Gyekye, 1995).

The concept of a taboo has been studied for a long time from different perspectives and disciplinary angles. The term is used by psychologists, sociologists, anthropologists and religious scholars, like Sigmund Freud, Franz Steiner and David Spain in psychology, sociology and anthropology, respectively. An ongoing debate is focused on the relevance of traditional cultural values and their role in solving contemporary problems. In Ghana the role of taboos in solving the contemporary environmental crisis is an ongoing debate. Conservatives reckon that traditional beliefs and practices play a 
significant and positive role in traditional societies and continue to exercise their influence on modern society. In practice, their impact, appears to diminish in comparison to traditional societies, due to factors such as western lifestyles and thinking, which has demonized African traditional and cultural values and conceives them as diabolic, savage and regressive. Conservatives think that modern society will benefit from the revival of traditional values. On the other hand, others are of the view that traditional beliefs and practices have outlived their usefulness in modern society.

The debate about the relevance of traditional values to social well-being has compelled anthropologists to posit a crucial distinction between "primitive" and "modern" societies, and taboos play an important role in establishing this distinction. British anthropologist Mary Douglas' analysis of the concept of pollution and taboos identified two types of cultures as far as the sanctions attached to taboos on pollution are concerned: "primitive" and "modern". Douglas notes that, with "modern" societies, pollution is a matter of aesthetics, hygiene or etiquette, which only becomes grave in so far as it may create social embarrassment. The sanctions are social sanctions: contempt, ostracism, gossip, perhaps even police action. However, in "primitive" societies, the effects of pollution are much more wide ranging. Gross pollution is a religious offence (Douglas, 1966:73). Taboos in "primitive" societies, by virtue of their religious status and sanctions from the supernatural, become reinforcement of reverence for status. Douglas notes that primitive religions are inspired by fear and at the same time are inextricably confused with defilement and hygiene. By this distinction between "primitive" and "modern" societies, anthropologists relegate the importance of traditional beliefs and practices to the "primitive" society. Thus, a "taboo" has little to contribute to modern society, since it relates solely to the "primitive" world. $\mathrm{Ne}$ - vertheless, 50 years after Purity and Danger, the Akan culture can be seen functioning in modern Ghanaian society, and so it would be inaccurate to describe it as a "primitive" belief. Rather it is a worldview that coexists in complex ways with modern Ghanaian society. I must stress here that, although we do not talk of a religion as "primitive", ideas and discourse about traditional values such as taboos have often been wrought in prejudice. This is because the use of the term "taboo" apparently dates back to the early colonial era, when it was assumed that it is associated with "primitive" societies. Sigmund Freud in his psychological evaluation of taboos relates them to "obsession and neurosis". However, in his Euro-centric approach, his analysis focuses on "people whom we ["civilized societies"] still consider more closely related to primitive man than to ourselves" (Freud, 1913:1), and on "those tribes which have been described by ethnographers as being the most backward and wretched".

Moreover, one may argue that the association of taboos with "primitive" societies is inaccurate on the basis of their universal nature. Durkheim calls taboos a "phenomenon that is universal". I must, however, point out that, this view is not without criticism. Based on the universal nature of taboos, Holden (2000) disagrees with anthropologists who assumed that taboos were a feature of "primitive" society. To Holden, it is a characteristic of any society. However, certain taboos may be prevalent within particular cultures. For instance, while environmental taboos, generally speaking, perform distinctly environmental functions of preserving vegetation and wildlife (Barre et al., 2009), what constitutes such taboos and the sanctions for breaking them may vary from one culture to the other. In a Ghanaian context, taboos vary among tribes. Nevertheless, I think such variations neither discredit the universal nature of taboos nor reduce it to the status of "primitive" beliefs. Rather, taboos make a worldview that exists 


\section{Tudományos múhely}

and functions in different ways based on the basic human nature as well the social and ecological contexts in which cultures exist.

In spite of marginalizing the supposed "savages" in his Euro-centric approach to taboos, Freud's (1913) narrative highlights a significant feature of taboos: they function to distinguish between "sacred" and "profane" entities in a culture. Freud notes that "the meaning of taboo branches off into two opposite directions. On the one hand it means to us sacred, consecrated: but on the other hand it means, uncanny, dangerous, forbidden and unclean". Emile Durkheim advances this idea of "sacred" and "profane", and observes that religion exists when the sacred is distinguished from the profane (Durkheim, 1982:129). He states that religion is a unified system of beliefs and practices relative to sacred things, that is to say, things set apart and forbidden.

In Durkheim's view, the "sacred" refers to things set apart by humans as requiring special religious treatment. It is believed to transcend everyday existence; it is potentially dangerous, awe-inspiring and fear inducing. On the other hand, the "profane" is the realm of routine experience. The attitudes and behaviour towards it are charged with negative emotions and hedged about by strong taboos. Certainly, within an African context, what Durkheim terms "sacred" and "profane" is on equal level of experience, so closely blended together and far from being cut off from one another. Nevertheless, the dichotomy of profane and sacred proposed by the Durkheimian sociology of religion is relevant to the African context, especially, to the Akan people of Ghana, as it underscores their worldview of the two dimensions to life: the spiritual (sacred) and the physical (profane).

While Parrinder sees ancestors as the originators and custodians of taboos (Parrinder, 1969:89), Fisher understands this relationship as follows: "a taboo is an offense against ancestors and the Supreme
Being" (Fisher, 1997:108). This claim by Fisher makes a taboo an obligation and not a choice, which in turn validates the punishment for breaking a taboo, a punishment that could come from God, ancestors or spirits. Taboos thus become "prohibitions which, when violated, produce automatically in the offender a state of ritual disability...only relieved when the relief is possible, by a ceremony of purification" (Barre et al., 2009:31). Although the supposed punishment from ancestors (including death, accidents or incurable illnesses) has been criticized as irrational and unscientific to the "modern" mind, nevertheless, the notion continues to thrive in most part of Africa. This, in a sense, demonstrates that the concept of "spirituality" is integral to African communal settings.

I argue that the traditional African belief in the religious order of the universe, in which the Supreme Being, the ancestors and other spiritual beings are thought to be actively engaged in the world of people, plays a significant role in the sustenance of this notion. The connection between taboos and ancestors, I think, has implications on how humans relate to their natural environment, considering the fact that these ancestral spirits supposedly reside in trees, rivers, rocks and animals, as Aye-Addo's (2013) study among the Akan people of Ghana revealed.

\section{The Classification of Taboos}

In the literature taboos are classified according to their roles in society. However, careful observation reveals that there can never be a neat categorisation. Osei (2006) groups taboos into cultic, moral (see Ofosuhene, 2006 also), economic, political, scientific and environmental taboos. Another group may relate to the prevention of criminal behaviour (Cassirer, 1972) and ensuring discipline in society, like environmental taboos, which ensure the conservation of the environment and biodiversity (Toledo, 2000; Chemhuru-Masaka, 2010) and can 


\section{Tudományos múhely}

also be considered as economic and scientific taboos due to the economic role they play in the agricultural and nomadic communities indigenous in Africa. Manyike and Evans note that "within an African context, taboos play an important role between the interaction of living members" (ManyikeEvans, 1998:223). Haralambos and Holborn also talk of taboos serving as "guidelines that direct conduct in particular situations" (Haralambos-Holborn, 2000:4).

Gorer (1965) and Ariès (1974) talk of death taboos, considered as a form of sequestration reinforcing the boundaries between living and dead bodies. Death taboos fit neatly into the category of the "cultic taboos" of Osei (2006). Death is seen as an illusion and can thus be discussed more openly. Death seems to have no relevance within the monumentality of modernity. It would not be far-fetched to argue that this relativism underlay an outlook on suppressing death as the mirror of the senselessness of life. If cultural values have only a relative significance in a disenchanted world and they point to no ultimate state, then it is futile to speak and think of death as if it could lead to an ultimate state. People can go about their daily lives without having to confront death as reflecting the senselessness of their routines. In short, modern relativism constitutes an unacknowledged source of the death taboo.

It is observed that though taboos defy categorisation, grouping them is of benefit to the understanding of taboos. Categorisation clearly shows that these sanctions on do's and don'ts regulate every aspect of human behaviour. They range from the legal and social through the economic and environmental to the moral dimension of human existence. They regulate the life of an individual from pregnancy through birth to death and beyond, as envisaged in the worldview of indigenous African societies. Little attention is paid to political taboos in the discussion on the categorisation of taboos. As this group of taboos closely relates to governance, they are analysed under taboos and governance.

\section{INDIGENEITY IN AFRICA}

Broadly speaking, the rise of indigenous peoples' civil rights movements in Africa is closely related to the United Nations' efforts at raise global awareness around the issue and the opening up of public forums for peoples to share their stories (Crawhall, 2006). Inevitably, issues debated as to the conception and definition of indigeneity at global level also recurs in case of Africa. The term "indigenous" may appear strange in an African context, yet it emerged as an important rallying point for highly marginalised indigenous communities. At the same time, classifying peoples as indigenous and non-indigenous would trigger a conflict between ethnic groups and recognition as marginalised minorities instead of indigeneity (Crawhall, 2006).

It is misleading to conceive indigeneity only in a relation to European settlers and domination. Indigenous peoples in Africa are victims of conceptual definitions espoused by non-African experts. Kingsbury argues that although the claims of indigenous peoples are similar across the continent, the characterisation of the concept indigenous peoples and their rights thereof would considerably vary based on their historical background and socio-cultural constitutions (Kingsbury, 1998:414). Indigeneity is not an absolute state, rather it is a political claim in the context of perceived marginalisation and vulnerability (Crawhall, 2006). Hence it is a relative concept that should be perceived case-by-case. In that sense it is defective to define indigeneity only based on the Blue Water Theory (i.e. conquest by Europeans who crossed the sea and conquered the "New Worlds"). In contrast, the S'ami people's case (in Norway) disproves the Blue Water Thesis, since the subjugation of the $\mathrm{S}^{\prime}$ ami was internal rather than external by the mainstream 
society. Despite the source of subjugation, they are recognised as indigenous peoples and have successfully established the $S^{\prime}$ ami Parliament.

To bridge the concepts of indigeneity in the West and in Africa, the historic experiences of the indigenous peoples of Africa is compared to those of indigenous peoples in other countries. The aborigines of Australia and the indigenous peoples of Africa were regarded by the colonisers as "uncivilised" or "savage", and their lands were considered as ownerless (terranullius). The difference between the two is that while the settlers' dominance in Australia still persists, in the case of Africa, the colonisers have withdrawn. African politicians would argue that white colonialists' withdrawal after decolonization mean that all African peoples are indigenous or that the concept "indigenous" is not applicable to Africa at all. Such conclusion comes from a misunderstanding of the history and the realities of indigenous peoples in Africa. Europe withdrew politically from Africa, granting independence to African administrations and liberation movements, and the new African elite consisted of those with the capacity to run the "new states" (Crawhall, 2006).

Considering the historic process of forming African states, all African states were created by colonial powers or with the help of European powers, and the current African states inherited this status quo. Makere Stewart-Harawira argues that the new African states established their authority over indigenous peoples within the frontiers created by former colonial powers (Stewart-Harawira, 2005:107). Political leaders came from circles with the closest relationship with Europeans (for example, emperor Haile Selassie I and Emperor Menelik II of Ethiopia, who trace their origin and authority back to Solomonic dynasty), namely the agricultural peoples who had adopted the European mode of capitalist system (Crawhall, 2006). In addition to multi-ethnic empires demarcated by Euro- pean, African states inherited the Western legal system and legal institutions, as opposed to African traditional institutions and customary laws. The bottom line is that the subjugation of African indigenous peoples and their political institutions have continued up to the present. Stewart-Harawira contends that "in the newly created states, indigenous peoples' traditional cognitive and social patterns, modes of governance and ontological world views were identified as obstacles to development and at odds with those of an economically based society" (Stewart-Harawira, 2005:108).

As per African Commission on Human and Peoples' Rights (ACHPRs) and international mechanisms dealing with indigenous peoples' rights, indigenous peoples in Africa are generally understood as nomadic and semi-nomadic pastoralists and huntergatherers, marginalized and discriminated peoples, "...their cultures and ways of life differ considerably from the dominant society and their cultures are under threat, in some cases to the extent of extinction. A key characteristic for most of them is that the survival of their particular way of life depends on access and rights to their traditional land and the natural resources thereon".

Such a characterisation excludes the majority of the people who have already changed their means of livelihood but are inherently indigenous people. The concept and the concern of African indigenous peoples have not been taken seriously by African states. Until recently, the participation of African states and African indigenous peoples in international indigenous peoples' movement have almost been nonexistent. For instance, unlike the contentious debates in the process of adoption of international treaties such as United Nations Declaration on the Rights of Indigenous Peoples (UNDRIPs) among nations (for example: Canada, USA, Australia) (Mattias, 2007:8385; Minde, 2008). ACHPR welcomes UNDRIPs declaring its importance to enhance 


\section{Tudományos múhely}

the rights of indigenous peoples in Africa. African states are the passive recipients of international instruments concerning indigenous peoples. Given the African indigenous peoples' silence and the fact that African states are not serious enough to be on the side of indigenous peoples' claims; the adoption UNDRIPs can neither increase the moral responsibility of the state agents towards disadvantageous indigenous peoples nor it has legal force on them. However, the role of regional organisations, such as the Indigenous Peoples of Africa Coordinating Committee's (IPACC) in advocating the interests of the indigenous peoples of Africa cannot be underestimated. For instance, IPACC reminded the UN Permanent Forum on Indigenous Issues (UNPFII) that three points needed to be considered when came to indigeneity in Africa: partnership, participation and pluralism. This position was mainly based on indigenous peoples' claim that democracy had to be more inclusive, tolerant of diversity and participatory (Crawhall, 2006).

\section{The Traditional Worldview of the AKan PEOple}

Ghana is made up of a lot of tribes, including the Akan, the Ewe, the Ga's, the Guan etc. The Akan occupy about six of the ten regions of Ghanam namely: Ashanti, the Eastern, the Central, the Western, BrongAhafo and some part of the Volta Regions. This ethnic group consists of tribes such as the Agona, Ahafo, Ahanta, Akuapem, Akwamu, Akyem, Aowin, Asante, Assin, Fante and Kwahu. The 2010 population census reports that the Akan constitute about $53 \%$ of the total population, with a headcount of $24,658,823$. They are mainly found in the southern and middle part of Ghana. However, a minority Akan population is also found in La Cote D'Ivoire. The traditional occupation of the Akan are farming and fishing. However, as a result of migration in search of jobs, Akans may also be found in the northern regions of Ghana engaged in different occupations other than farming and fishing. Traditionally, the Akan are matrilineal, they inherit from the mother's side. The only exception to this form of inheritance is the Akuapem of Larteh and Mampong. Though the Akwapim's are Akan, they inherit from the father side (Pobee, 1979:44). An implication of matrilineal inheritance is that nephews inherit the properties of their uncles. However, with the passing into law the Interstate Succession Law, PNDC Law 111, this system of inheritance was abolished.

According to Awuah-Nyamekye, the worldview of the Akan people is "the sum up of their core ideas about the universe and their role within it" (Awuah-Nyamekye, 2014:60). This understanding, mirrors Allan's (1985) view that "a worldview is a general way of looking upon the universe and our relation to it, a general set of assumptions about the meaning of life, about what is important and about how things work". Awuah-Nyamekye (2014) further notes that the worldview of the Akan people is "the product of systematic reflections on phenomena and experiences that their forebears have bequeathed to them." Accordingly, the Akan people's worldview is conjectural, but instead of remaining as something that exists merely at the theoretical stage, it is demonstrated in real life through the people's culture. As Kalu rightly points out, the Akan indigenous cultural pattern is influenced by worldviews which serve as a reservoir of knowledge (Kalu, 2001:228). They are stored in myths, proverbs and folklores.

In the Akan worldview, the world comprises of the supernatural (or the spiritual) and the living (or the physical), with the former having control over the affairs of the latter. For human to enjoy the good things of life (such as fertility, bumper harvest, good health etc.) and avoid all the negative things of life (including sudden deaths, incurable diseases, recurring accidents etc), 


\section{Tudományos múhely}

they have to able to comprehend the diverse constituents of both the spiritual and the physical aspects of the universe and how to relate to each. The Akan generally believe that there are evil spirits (Amoah, 1998) that can inflict bad luck on humanity and they must therefore seek protection from superior beings. Amoah thinks protection is sought in maintaining a harmonious relationship between humanity, nature and the spirits. This partly explain why their life and thinking are influenced by the supernatural. In this regard, Larbi (2002) posits that: "The Akan think that everything that happens to a human being has a religious interpretation. To them, behind the physical is the spiritual; behind the seen is the unseen. Every event here on earth is traceable to a supernatural source in the spirit realm. From the same source, therefore, lies the ultimate succour."

According to both Gyekye (1995) and Mbiti (1990), in the Akan conceptualization of the universe conceives that the universe is unitary, and it is essentially spiritual to the extent that there is continuous interaction between the spiritual world and human beings. Any attempt at making a distinction between the spiritual and the physical in the Akan thinking is likely to be met with mixed feelings, if not total disapproval. This is because the consciousness of the supernatural permeates all thoughts and actions. Gyekye accentuated that "what is primarily real is spiritual” (Gyekye, 1995:69). In Mbiti's opinion, the spiritual and the physical are "two dimensions of one and the same universe. These dimensions dove-tail each other to the extent that at times and in places one is apparently more real than, but not exclusively of the other" (Mbiti, 1990:203).

Moreover, several scholars (Mbiti, 1990) have observed that religion is deeply rooted in all aspects of African life: their worldviews are underscored by a common system of religiousness. African societies, Kalu Ugbu (as quoted in Ogiozee, 2009:14) remarks, "[are] couched in religious, numinous terms: creation was the act of a Supreme Being utilizing the services of subaltern gods." Accordingly, Mbiti observes: "Africans are notoriously religious and each people has its own religious system with a set of beliefs and practices. Religion permeates into all the departments of life so it is not easy or possible to isolate it [from other aspects of African society and culture]" (Mbiti, 1990:1).

A study of these religious systems is, therefore, a study of the peoples themselves in all the complexities of traditional and modern life. Consequently, the Akan worldview, one may argue, is underpinned by its indigenous religion. Elorm-Donkor's study of the African worldview confirms this assertion. He reveals: "In the traditional Akan community almost every communal event is connected with religion... [and] wellbeing in life is guaranteed by a congenial moral relationship between human and the spirit entities of their community. It is believed that when left on their own to provide for the spiritual, physical and psycho-social resources that they need for mastering their environment [including managing environmental problems], humans are found to be limited and inadequate. Therefore there is constant need for a moral relationship that is both interdependent and interconnected" (Elorm-Donkor, 2012:3-4).

Owing to the fact that the Akan worldview is underpinned by its indigenous religion, all aspects of creation are respected. According to Awuah-Nyamekye, within Akan societies, while all aspects of the universe are seen as God's creation and must be protected, elements of creation that serves as sources of sustenance for human life - trees, animals and rivers are given more attention (Awuah-Nyamekye, 2014:62). Similarly, Daneel and Ranger (as cited in Taringa, 2006:191-192) relate the environment-friendliness of the indigenous religion in the African worldview. They opine: “...Traditional African ecology... is inseparably linked with traditional religion. 


\section{Tudományos múhely}

Environmental protection is sanctioned by the creator God and the ancestors of the land" (Taringa, 2006). "African religious ideas were very much ideas about relationships, whether with other living people, or with spirits of the dead, or with animals, or with cleared land, or with the bush" (Ranger, 2008).

However, the introduction of Western education and religions (which are underpinned by Western worldviews) in Ghana may have had an effect on the worldviews of the Akan people of Ghana. Suggesting that the Akan worldview prior to their encounter with colonialism would not have been exactly as it is today, thereby affirming Hart's (2010) observation about worldview's "susceptibility to change." Nevertheless, one can still talk of a unique Akan worldview. This is because the core constituents of the traditional Akan worldview (including, the belief in the Supreme Being, cults associated with various divinities, nature spirits, rituals, ancestral spirits, a belief in magic and fear of witchcraft) still continue to influence behaviour. Moreover, some surveys among the Akan people have pointed out that, the encounter between Akan indigenous religion and culture and monotheistic religions like Christianity and Islam did not lead to a domination of the latter over the former. Acquah (2011) notes: "Although conversion of Akan indigenous religious adherents to these monotheistic religions was overwhelming in terms of numbers, these converts did not completely abandon or denounce their traditional religious beliefs and practices; they still served as important religious mediation for expressing their new faith. Their conversion to these monotheistic religions amounted to adding onto their old religion the relevant religious elements found in the new religions which served their present need in life."

Similarly, Shorter has contended that the African Christian does away with "remarkably little of his former non-Christian outlook" (Shorter, 1975:7). Furthermore, I argue here that the influences of Western views on the Akan's worldview have implications to the management of their ecological issues. This is because people's worldviews influence their understanding and evaluation of things.

The Akan worldview is underpinned by its indigenous religion. I agree with AwuahNyamekye (2014) that the Akan people have a "religious worldview", just as Thomas rightly points out that "religion permeate every aspect of [the African's] life and shape how they perceive themselves and the world" (Thomas, 2015:42). This makes it very important to throw more light on some aspects of the religion of the Akan people.

The Akan Indigenous Religion comes under the bigger umbrella of the African Traditional Religions. African Traditional Religions, also referred to as African Indigenous Religions or African Ethnic Religions, is a term referring to a diversity of religions indigenous to the continent of Africa. Similar to ethnic religions in other parts of the world, African religious traditions are defined mainly along community lines. These traditional African religions also play a large part in the cultural understanding and awareness of the people of their communities.

Central to the Akan religious ideas is the strong belief in a community of spirits. These several spirits range from the $\mathrm{Su}$ preme Being or creator god (Nana Onyame/Onyankopon), gods/goddesses (Abosom) and the earth deity (Asaase Yaa) to the ancestral spirits (Nananom Nsamfo). Onyankopon refers to the supremacy of God. $\mathrm{He}$ is seen as the creator of the universe. This belief in Onyankopon as the creator can be argued to have ecological ramification as it suggest that all creation (including trees, animals and rivers) was created by Onyankopon and humanity as stewards have the responsibility to protect and conserve the environment or nature. Agyarko (2013) recapitulates the influence of the 
Akan concept of God (Onyankopon/Onyame) and its implications on the people's attitude towards creation thus:

All human and non-human relations are affected by the belief that we all belong together in God. Onyame is immediately present to each creature through their sunsum (spirit). This view of the immediacy of God to creatures has consequences for the way the Akan, at least theoretically, value and treat one another and other creatures. Onyame nti ("for the sake of God"), one acts or refrains from acting against another person or non-human forms of life. Asaase Yaa, the earth goddess, is next to Onyankopon and is responsible for fertility. In some sense, Asaase Yaa is also the "custodian of morality and social decorum, the traditional ethical code" (Okorocha, 1987:52).

Next to Asaase Yaa are the Nananom Nsamanfo (ancestral spirits), literally described as the "living dead". Though they are the departed members of the community, they are still considered to be living and believed to influence the lives of the living. Not every dead person is considered an ancestor in the Akan society. For one to qualify as an ancestor, the person needs to have a peaceful death (abodweewuo), must be a married person with children, and live an exemplary life etc. (Rattray, 1954; Opoku, 1978). The abosom (gods/ goddesses) are another central element in Akan indigenous religion. These deities are believed to reside in natural substances such as rivers, trees, mountains, caves and animals. Awuah-Nyamekye's study of the Akan people of Berekum revealed that "all the deities in Berekum have particular animals or trees as taboos. These beliefs influence Berekum people's attitudes towards natural objects and the relationship between natural object and deities explains why contravening any of the taboos in relation to natural objects is a matter of concern to the entire community" (Awuah-Nyamekye, 2014:68-67). This may explain why in the Akan society most taboos are taken seriously, as they are believed to have been imposed by traditional rulers and priests on behalf of the people and in the general interest of the community. Unlike ordinary wrongs, taboos are taken more seriously and the mmusu (serious sin) type of taboos may require blood sacrifices for the pacification and forgiveness of the gods and ancestors, who might, according to traditional belief, otherwise pour their wrath on the living in the form of epidemics, drought and infertility.

Religion, to the Akan, is generally perceived as a tool for survival and for enhancing life in its broad sense (Amoah, 1998). To be religious in the Akan worldview entails active participation in rituals such as sacrificing, praying and seeking esoteric knowledge from spirits as well as maintaining a good relationship with fellow human beings. Moreover, it involves soliciting the assistance of numerous spirits to overcome social problems and evil powers believed to exist in the world. More importantly, being religious is maintaining harmony not only with fellow human beings, but also with nature (including the environment) and the spirits.

\section{Taboo Among the Akans}

In African societies, taboo primarily serves the purpose of ritual protection or ritual hygiene. Ayegboyin and Jegede confirm the fact that taboo is embedded in the myths and religions of Africans and in most African countries and communities, taboos are numerous, they cover almost every aspect of Africans' life and they are taken seriously (Ayegboyin-Jegede, 2009:1). There are taboos associated with different initiations and celebrations such as childbirth, marriage, death and burial.

In his study of the Akan people, Gyekye (1995) points out that the closest equivalent to a taboo in the Akan are "akyiwade", i.e. that which is forbidden or prohibited, and "musuo". The later term is however 
reserved for prohibitions against very serious or extraordinary moral evils such as murder, suicide, rape, incest and religious sacrilege. Therefore while all akyiwade are taboos, not all taboos are musuo. Among Akans, traditional rulers and chief priests are the custodians of taboos. The enforcement process of these taboos is in line with the oath Akans swear to the ancestors. The misuse of an oath is the transgression of an ethnic taboo. Taboos become the traditional commandments through which leaders are protected from social and spiritual ambivalences. By this, a taboo among the Akans is an obligation and not a choice.

Consequently, most taboos are taken seriously since they are believed to have been imposed by traditional rulers and priests on their behalf and in the general interest of the community. They may be promulgated and transmitted in the form of religious ordinances, creeds or vows.Since these taboo sanctions are believed to be instantaneous and "automatic", unlike sanctions in other religions that have to wait till the end of life or stand to be mitigated by God's mercy and forgiveness, most people will not intentionally violate them, even if they are uncertain of their metaphysical presuppositions. The sins or offences which are believed to be taboo, because punishments for them are automatic, carry their own deterrents with them and there is no doubt that most people refrain from committing them for fear of the more or less inevitable consequences (Ackah, 1988:99). As a result, the value of taboos as a source of moral guidance and motivation for social order cannot be dismissed theoretically (Osei, 2006).

Within some African societies (including the Akan), people are reserved to question or challenge taboos because they are embedded within their cultural and religious practices. When something is considered a taboo, it must not be talked about, done, mentioned, touched, or looked at (Madu, 2002:65). Thody (1997) identifies five categories of the "forbidden": actions (do not do it, be it, or indulge in it); nourishment (do not eat or drink); words and themes (do not say it and do not talk about it); ideas, books and pictures (do not think it, write it, paint it, print it or show it); and signs (do not make yourself look that). Therefore, taboo is a precautionary principle that represses open dialogue as it compels adherents to comply or face punishment, which could either be moral (weighs on the breaker's conscience) or stigma (be subject of ridicule). The religious roots of taboo themes connote that: “....all prohibited acts or taboos are crimes in African traditional religion and any person committing any of them is regarded a criminal and is punishable. In traditional African society the sacred and the secular are inseparable... what religion forbids or condemns society also forbids and condemns."

It is believed that among the Akan, breaking taboo results in either a punishment or suffering from bad conscience (e.g., feeling sick or guilty). It appears there is an inner force that comes into action. Violation may even end in a partial surrender to the taboo as Freud (1944, cited in Madu, 2002:65) wrote in his Totem and Taboo: "A person who breaks a taboo will be tabooed himself or herself, because he or she has the dangerous threat of luring others into following his or her example."

As Thody (1997) rightly argues, taboos, unlike laws, are for the most part irrational and hard to defend on practical or humanitarian ground. Christianity and Islam, coupled with modernity, claim that taboos stem from myths that do not correspond to historical chronology and therefore, belief in the potency of taboo is tantamount to primitivism, backwardness and superstition. To obey a taboo is therefore considered absurd and incongruous with development. But taboos in Africa are truth forms that are independent of the confines of time. A taboo is sacred; the fact of its potency can be found only in the depth of the mind, where merely rational thought cannot penetrate 


\section{Tudományos múhely}

so as to discover its reality (AyegboyinJegede, 2009).

Although taboos, especially in the context of African societies, are associated with the supernatural and religion and infringement results in an automatic penalty without human or divine mediation taboos are "overridable" (Ayegboyin-Jegede, 2009). This means they are not construed as absolute or eternal, and therefore unchanging, rules. Among the Akans for instance, this overridability of taboos is expressed in many ways. While it is (generally) a taboo to carry anything in a palm leaf basket to the king's palace, it is also, emphatic that notwithstanding this prohibition, it is not a taboo to carry nuggets of gold in a palm leaf basket into the king's palace (Ofosuhene, 2006). Taboos are therefore, over-ridable, since they permit reasonable exceptions as necessitated by special circumstances. Within Akan societies and using development as a benchmark, one may argue that some taboos are counter-productive since they do not support the well-being of the people concerned. Taboos that encourage cruel widowhood rites and those that place restriction on farming activities are dehumanizing and affect economic productivity respectively. No matter how unimportant or unreasonable taboos may appear to the modern mind in details, embedded in them are "germinant principles of social progress and moral order" and therefore "the cornerstone of the whole social order" (Cassier, 1992:106). Although Cassier saw taboos associated with African Traditional Religion (ATR) as "savage taboos" and so sidelined from moral discourse, since ATR is not considered among the major religions, my analysis in the following discussion will point out that, on the contrary, taboos associated with ATR are not savage as they have rational and scientific explanations and ethical values. Key among them is the significant role of taboos in Akan people's indigenous ways of preserving the environment.

\section{Conclusion}

It is an undeniable fact that enormous pressure and influence had been brought to bear on the practices of taboos among Akans. Nevertheless, in the area of governance it is a feature which cannot be done away with. This is because when the elements are not adhered to, such as swearing, which is a means to obtain the authority of the people, would amount to a usurpation of the authority of the people and players in charge of governance cannot hold themselves as such.

\section{REFERENCES}

Ackah, A. C (1988): Akan Ethics. A Study of the Moral Ideas and the Moral Behaviour of the Akan Tribes of Ghana. Ghana University Press, Accra.

Acquah, Francis (2011): Christian-Muslim Relations in Ghana from 1920 Through the Present. Unpublished Doctoral Thesis, University of Exeter, London.

Agyarko, Robert (2013): God of Life: Rethinking the Akan Christian Concept of God in the Light of the Ecological Crisis. The Ecumenical Review, Vol. 65, No. 1, https://doi.org/10.1111/ erev. 12026.

Allan, Keith - Burridge, Kate (2006): Forbidden Words. Taboo and the Censoring of Language. Cambridge University Press, Cambridge, https: //doi.org/10.1017/cbo9780511617881.

Amoah, Elizabeth (1998): African Indigenous Religions and Inter-Religious Relationship. Mansfield College, Oxford.

Aries, Philippe (1974): Western Attitudes Towards Death. From the Middle-Ages to the Present. Johns Hopkins University Press, Baltimore.

Awuah-Nyamekye, Samuel (2014): Managing the Environmental Crisis in Ghana. The role of African Traditional Religion and Culture with Special Reference to the Berekum Traditional Area. Cambridge Scholars Publishing, Cambridge.

Aye-Addo, Charles S. (2013): Akan Christology. An Analysis of the Christologies of John Samuel Pobee and Kwame Bediako in Conversation with the Theology of Karl Barth. Wipf and Stock Publishers, New York.

Ayegboyin, Deji - Jegede, Charles (2009): Divinities. In: Asante, Molefi - Mazama, Ama (eds.): Encyclopedia of African Religion. Sage, 


\section{Tudományos múhely}

Thousand Oaks, 210-213, http://dx.doi.org/ $10.4135 / 9781412964623$.

Barre, Rita - Grant, Miriam - Draper, Dianne (2009): The Role of Taboos in Conservation of Sacred Groves in Ghana's Tallensi-Nabdam District. Social and Cultural Geography, Vol. 10, No. 1, 25-39, https://doi.org/10.1080/14649360802553194.

Brempong, Owusu (2006): Chieftaincy and Traditional Taboos. In: Odotei, Irene - Awedoba, Albert K. (eds).: Chieftaincy In Ghana. Culture, Governance and Development. Sub-Saharan Publishers, Legon.

Busia, Kofi. A. (1968): The Position of the Chief in the Modern Political System of Ashanti. A Study of the Influence of Contemporary Social Change on Ashanti Political Institution. Frank Cass and Company Ltd., London.

Cassirer, Ernst (1972): An Essay on Man. Yale University Press, New Haven.

Chemhuru, Munamato - Masaka, Dennis (2010): Taboos as Sources of Shona People's Environmental Ethics. Journal of Sustainable Development in Africa, Vol. 12, No. 7, 121-133.

Crawhall, Nigel (2006): Indigenous Peoples' in Africa. Occasional Paper 03/2007, Norwegian Church Aid, Oslo.

Crystal, David (1995): The Cambridge Encyclopedia of the English Language. Cambridge University Press, Cambridge.

Durkheim, Emile (1982): The Elementary Forms of Religious Life. George Allen \& Unwin, London.

Douglas, Mary (1966): Purity and Danger. An Analysis of the Concepts of Pollution and Taboo. Routledge, New York.

Elorm-Donkor, Lord (2012): African Worldview and Christian Pneumatology:Divergences and Convergence. Didache Faithful Teaching, Vol. 12, No. 1.

Fisher, Robert B. (1997): West African Religious Traditions. Orbis Books, New York.

Freud, Sigmund (1913): Totem and Taboo. Moffat, Yard \& Co., New York.

Gorer, Geoffrey (1965): Death, Grief, and Mourning in Contemporary Britain. Cresset, London.

Gyekye, Kwame (1995): An Essay on African Philosophical Thought. The Akan Conceptual Scheme. Temple University Press, Philadelphia.

Haralambos, Michael - Holborn, Martin (2000). Sociology. Themes and Perspectives. Collins, London.

Hart, Michael A. (2010): Indigenous Worldviews, Knowledge, and Research: The Development of an Indigenous Research Paradigm. Journal of Indigenous Voices in Social Work, Vol. 1, No. 1.

Holden, Lynn (2000): Encyclopedia of Taboos. ABC CLIO Ltd, Oxford.

Kalu, Ogbu U. (2001): The Sacred Egg: Worldview, Ecology, and Development in West Africa. In: Grim, John A. (ed.): Indigenous Tradition and Ecology. Harvard University Press, Cambridge, 226-248.

Kingsbury, Benedict (1998): "Indigenous Peoples" in International Law: A Constructivist Approach to the Asian Controversy. The American Journal of International Law, Vol. 92, No. 3, 414-457, https://doi.org/10.2307/2997916.

Larbi, Emmanuel K. (2002): The Nature of Continuity and Discontinuity of Ghanaian Pentecostal Concept of Salvation in African Cosmology. Asian Journal of Pentecostal Studies, Vol. 5, No. 1, 87-106.

Levine, Michael (1986): The Subject is Taboo. Modern Language Notes, Vol. 101, No. 5, 977-1002, https://doi.org/10.2307/2905707.

Madu, Sylvester N. (2002): Health Complaints of High School Students in the Northern Province and Taboo Themes in their Families. South African Journal of Education, Vol. 22, No. 1, 65-69.

Manyike, R. W. - Evans, A. C. (1998): Attitudes of University of Venda Students Towards Mental Illness: Western or African. In: Madu, Sylvester et al. (eds.): In Quest for Psychotherapy for Modern Africa South Africa. University of the North Press, South Africa, 220-234.

Mattias, Ahrén (2007): The UN Declaration on the Rights of Indigenous Peoples. How Was It Adopted and Why Is It Significant? Gáldu Čála, No. 4, 1-139.

Mbiti, John S. (1990): African Religions and Philosophy. Heinemann, Oxford, Portsmouth.

Minde, Henry (2008): Indigenous Peoples. Self-determination, Knowledge, Indigeneity. Eburon, Delft.

Ofosuhene, K. Godwin (2006): The Concept of God in the Traditional Religion of Akan and Ewe Ethnic Groups Compare to the Bible. www.academia. edu/1964497/The_Concept_of_God_in_the_ Traditional_Religion_of_the_Akan_and_Ewe_ Ethnic_Groups_Compared_the_Bible.

Okorocha, Cyril C. (1987): The Meaning of Religious Conversion in Africa: The Case of the Igbo of Nigeria. Gower, Brookfield.

Ogiozee, Olena P. (2009): The Value of the Continuity between African and Old Testament Worldviews. ProQuest LLC.

Omobola, Odejobi C. (2013): An Overview of Taboo and Superstition among the Yoruba of Sou- 


\section{Tudományos múhely}

thwest of Nigeria. Mediterranean Journal of Social Sciences, Vol. 4, No. 2, https://doi.org/10.5901/ mjss.2013.v4n2p221.

Olowu, Dele - Sako, Soumana (eds.) (2002): Better Governance and Public Policy. Capacity Building and Democratic Renewal in Africa. Kumarian Press, Bloomfield.

Osei, Joseph (2006). The Value of African Taboos for Biodiversity and Sustainable Development. www.researchgate.net/publication/265194890_The_ Value_of_African_Taboos_for_Biodiversity_ and_Sustainable_Development.

Opoku, Kofi A. (1978): West African Traditional Religion. FEP International Limited, Ghana.

Parrinder, Geoffrey (1969): Religion in Africa. Praeger Publishers, New York.

Pobee, John S. (1979): Towards an African Theology. Abingdon, Nashville.

Ranger, Terence (2008): Evangelical Christianity and Democracy in Africa. Oxford University Press, New York.

Rattray, Robert S. (1954): Religion and Art in Ashanti. Oxford University Press, London.

Schwartz, John (2009): Two German Killers Demanding Anonymity Sue Wikipedia's Parent. The
New York Times, 12 November, www.nytimes.com/ 2009/11/13/us/13wiki.html?_r=1.

Steiner, Franz (1956): Taboo. Cohen \&West Ltd., London.

Stewart-Harawira, Makere (2005): The New Imperial Order. Indigenous Responses to Globalization. Huia Publishers, New Zealand.

Shorter, Aylward (1975): African Christian Theology. Geoffrey Champman, London.

Taringa, Nisbert (2006): How Environmental is African Traditional Religion? Exchange, Volume 35, No. 2, 191-214, https://doi.org/10.1163/15 7254306776525672 .

Thody, Philip (1997): Don't Do It! A Dictionary of the Forbidden. St. Martin's Press, New York.

Thomas, Douglas E. (2015): African Traditional Religion in the Modern World. McFarland, Jefferson, NC.

Toledo, Victor M. (2000): Indigenous Knowledge on Soils: An Ethnoecological Conceptualization. In: Barrera-Bassols, Narciso - Zinck, Alfred (eds.): Ethnopedology in a Worldwide Perspective. An Annotated Bibliography. ITC Publication, Enschede. 